\title{
A chemosynthetic weed: the tubeworm Sclerolinum contortum is a bipolar, cosmopolitan species
}

\author{
Magdalena N. Georgieva ${ }^{1,2^{*}}$, Helena Wiklund ${ }^{1}$, James B. Bell ${ }^{1,3}$, Mari H. Eilertsen ${ }^{4,5}$, Rachel A. Mills ${ }^{6}$, \\ Crispin T. S. Little ${ }^{2}$ and Adrian G. Glover ${ }^{1}$
}

\begin{abstract}
Background: Sclerolinum (Annelida: Siboglinidae) is a genus of small, wiry deep-sea tubeworms that depend on an endosymbiosis with chemosynthetic bacteria for their nutrition, notable for their ability to colonise a multitude of reducing environments. Since the early 2000s, a Sclerolinum population has been known to inhabit sediment-hosted hydrothermal vents within the Bransfield Strait, Southern Ocean, and whilst remaining undescribed, it has been suggested to play an important ecological role in this ecosystem. Here, we show that the Southern Ocean Sclerolinum population is not a new species, but more remarkably in fact belongs to the species $\mathrm{S}$. contortum, first described from an Arctic mud volcano located nearly 16,000 km away.
\end{abstract}

Results: Our new data coupled with existing genetic studies extend the range of this species across both polar oceans and the Gulf of Mexico. Our analyses show that the populations of this species are structured on a regional scale, with greater genetic differentiation occurring between rather than within populations. Further details of the external morphology and tube structure of S. contortum are revealed through confocal and SEM imaging, and the ecology of this worm is discussed.

Conclusions: These results shed further insight into the plasticity and adaptability of this siboglinid group to a range of reducing conditions, and into the levels of gene flow that occur between populations of the same species over a global extent.

Keywords: Siboglinidae, Polychaeta, Annelida, Antarctica, Gene flow, Deep-sea, Connectivity, Hydrothermal vent, Cold seep, Biogeography

\section{Background}

The vastness and inaccessibility of the deep sea has challenged scientists seeking to understand its diversity $[1,2]$. A major area of this research concerns improving knowledge on the ranges of deep-sea species, which has become particularly pertinent in light of growing human impacts in this environment [3]. Molecular tools have been applied to this field and have revealed that certain deep-sea species with widespread distributions can exhibit similar morphology but considerable genetic differentiation between regions, and may thereby represent several

\footnotetext{
* Correspondence: eemng@leeds.ac.uk

'Life Sciences Department, Natural History Museum, London, UK

${ }^{2}$ School of Earth and Environment, University of Leeds, Leeds, UK

Full list of author information is available at the end of the article
}

closely related but geographically restricted species - so called 'cryptic species' [4-8]. Contrastingly, other studies have also revealed that some taxa can indeed be incredibly widespread, displaying distributions that can span both poles, i.e. bipolar. This pattern has been confirmed in bacteria and archaea $[9,10]$, in benthic foraminifera [11], deep-sea coral [12] and a lineage of the amphipod Eurythenes gryllus [8]. While there are problems with the use of molecular data to delimit species, the examination of genetic variation at multiple (both mitochondrial and nuclear) loci within an evolutionary context has become an important addition to our definition of a species alongside morphological, biological and ecological observations [13-15], as well as a critical tool in the investigation of species biogeography. Here we 
investigate the range and ecological adaptations of a deep-sea siboglinid tubeworm over near 16,000 km spanning from the Arctic to the Antarctic.

The family Siboglinidae is a monophyletic lineage of annelid worms comprised of the vestimentiferans, or giant tubeworms, the bone-eating genus Osedax, and two groups of slender tubeworms - Sclerolinum and the frenulates [16]. Siboglinidae is exceptional among the annelids due to this family's almost complete reliance on endosymbiotic bacteria for nutrition, and the unusual morphology which its members have adopted for this specialism [17]. The majority of siboglinids (except for Osedax and a number of frenulates capable of oxidising methane) harbour sulphur-oxidising symbionts [18] and are characteristically long, often acting like a 'bridge' between a sulphidic substrate where their posterior end is located, and oxygenated seawater into which they extend their anterior end [19].

Although siboglinids are found within all of the world's major oceans, the distribution and genetic structure of certain lineages is poorly constrained. Hydrothermal vent vestimentiferans endemic to the East Pacific Rise (EPR) are perhaps the best studied, where species such as Riftia pachyptila and Tevnia jerichonana show extensive ranges along the length of this mid ocean ridge system, while the degree of genetic differentiation between populations increases with distance $[20,21]$. Vestimentiferans that can colonise seeps, whale and wood falls have the potential to be even more widely distributed. The genus Escarpia is found in a variety of reducing environments, and occupies several ocean basins with the three described species Escarpia laminata, E. southwardae, and E. spicata occurring in the Gulf of Mexico (GoM), West Africa, and in the eastern Pacific respectively. However, while there is high genetic similarity between the three species, geographical and hydrological barriers still appear to limit gene flow between them [22].

The genus Sclerolinum, which forms the sister clade to the vestimentiferans [23], also exhibits a widespread distribution. The seven formally described species are reported from the northeast Atlantic [24, 25], GoM and Caribbean [26, 27], and southeast Asia [28, 29], however there are also a number of known but not currently described Sclerolinum populations from Antarctica, Hawaii [30], the Sea of Okhotsk [31] and off Kushiro, Japan $[32,33]$, that extend the range of this genus even further. This little studied genus of small, wiry tubeworms have also been found to possesses peculiar organisation that has made it challenging to determine its position in relation to other siboglinids, have been shown to perform important ecological functions within deep-sea sediments, and is capable of colonising a multitude of reducing environments [25-27, 29, 30, 34].
Remarkable substrate choice and geographical range is demonstrated by just one Sclerolinum species, $S$. contortum. Initially described from soft sediments at Håkon Mosby Mud Volcano (HMMV) [25], this species was later also found to be residing in the nearby cold seeps of the Storegga Slide, Norwegian Sea [35, 36] as well as in diffuse flow areas of the Arctic vents of Loki's Castle [37, 38]. Colonisation experiments in the northeast Atlantic have shown that in addition to soft sediments, S. contortum can inhabit wood, other decaying plant debris, as well as mineral substrates [39]. A population of Sclerolinum contortum notably also occurs within the cold seeps of the GoM, a distance of over $7600 \mathrm{~km}$ from the nearest northeast Atlantic population [27].

Considerable sampling of the deep waters around Antarctica in recent years has revealed this region to be much more diverse, and not as isolated as traditionally thought [40]. These exploration efforts have also shown that the Southern Ocean possesses a variety of deep-sea chemosynthetic habitats that include areas of high temperature and diffuse venting, cold seeps, and whale falls [41-44]. Hydrothermal activity is currently known to occur within the Bransfield Strait [41, 45], along the East Scotia Ridge [46], Pacific-Antarctic Ridge [47], Australian-Antarctic Ridge [48], and within Kemp Caldera [49], and to support unique vent ecosystems distinct from those of the main mid-ocean ridge systems [43].

Since 2001, Sclerolinum has been known to inhabit the sedimented hydrothermal vents of Hook Ridge, Bransfield Strait (Fig. 1) [41]. This population was recently suggested to play an important role in mediating the release of iron and manganese from sediments to the water column [34]. However while aspects of the habitat and function of this population have been investigated $[30,34]$, the morphology of these worms, their extent within the Southern Ocean, and how this population relates to other known Sclerolinum populations remain unknown. This study aims to provide a detailed description of the Antarctic Sclerolinum population, place it within a phylogenetic context and thereby establish its relationships to other Sclerolinum populations worldwide, and discern its extent and ecology within the Southern Ocean.

\section{Results}

\section{Systematics}

Phylum Annelida

Family Siboglinidae Caullery, 1914

Genus Sclerolinum Southward, 1961

Sclerolinum contortum Smirnov, 2000

(Figs. 2, 3 and 4) 

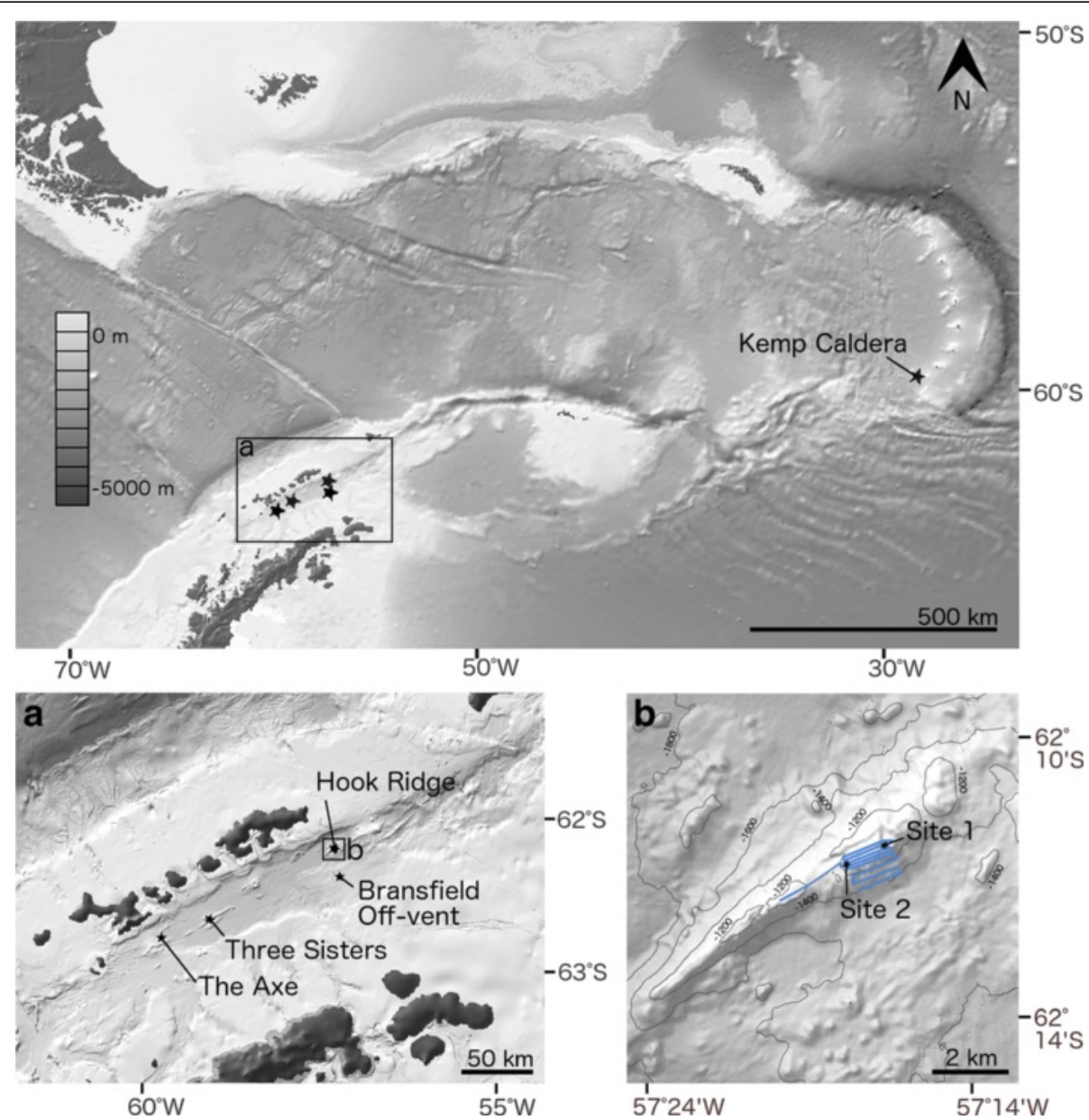

Fig. 1 Southern Ocean sampling sites from which Sclerolinum sp. was collected. Box (a) shows the locations of JC55 Bransfield Strait sampling locations, and (b) shows detail of Hook Ridge sampling sites (Hook Ridge Site 1 and Hook Ridge Site 2), as well as the path traversed by the SHRIMP (in blue). Map created using GeoMapApp (http://www.geomapapp.org) using data from the Global Multi-Resolution Topography (GMRT) Synthesis [92]

\section{Material examined}

Southern Ocean, Hook Ridge Site 1, 62.1969'S 57.2975 W, 1174 m depth: JC55_19 (RRS James Cook operation no.), 15 tube fragments. JC55_19, tubes attached to sampling gear (non-quantitative), 234 tube fragments [NHMUK 2015.1140-1146]. JC55_20, five tube fragments [NHMUK 2015.1153-1155]. JC55_21, 1 worm fragment with forepart, seven tube fragments [NHMUK 2015.1147-1152]. JC55_25, 29 worm fragments with forepart, 302 additional tube fragments [NHMUK 2015.1156-1157, 1188-1189 ( subset of examined material )]. Hook Ridge Site 2, 62.1924ㅇ $57.2783^{\circ} \mathrm{W}, 1054 \mathrm{~m}$ depth: JC55_30, eight tube fragments attached to sampling gear [NHMUK 2015.1158].

\section{Description}

Anterior extremity of tubes pale white in colour, thin walled $(2$ to $7 \mu \mathrm{m})$ and flattened. Posteriorly, wall thickness increases (to maximum of $28 \mu \mathrm{m}$ ) and tubes generally exhibit several smooth bends (Fig. 2a). Majority of tube is pale brown/green in colour (Fig. 2a-b), flexible and elastic, often possessing closely but irregularly spaced transverse wrinkles as well as faint longitudinal wrinkles on its outer surface (Fig. 3a), occasional microbial filament and rust patches are also present on outer tube surfaces. Tube walls are multi-layered, comprised of superimposed fibrous sheets in which fibres show an overall disorganised arrangement, inner tube surface shows a similar texture (Fig. 3c-d). Towards posterior extremity, tubes are increasingly thin walled and collapsed, outer tube wall generally smooth but with patches of attached sediment grains (Fig. 3b). Tube diameter ranges from 0.22 to $0.30 \mathrm{~mm}$, longest tube fragment measured $155 \mathrm{~mm}$. Several tubes exhibit branch-like abnormalities (Fig. 2e), a subset of Hook Ridge Site 1 tubes were very dark brown to black in colour (similar to tubes from Kemp Caldera, see later (Fig. 6b)). 


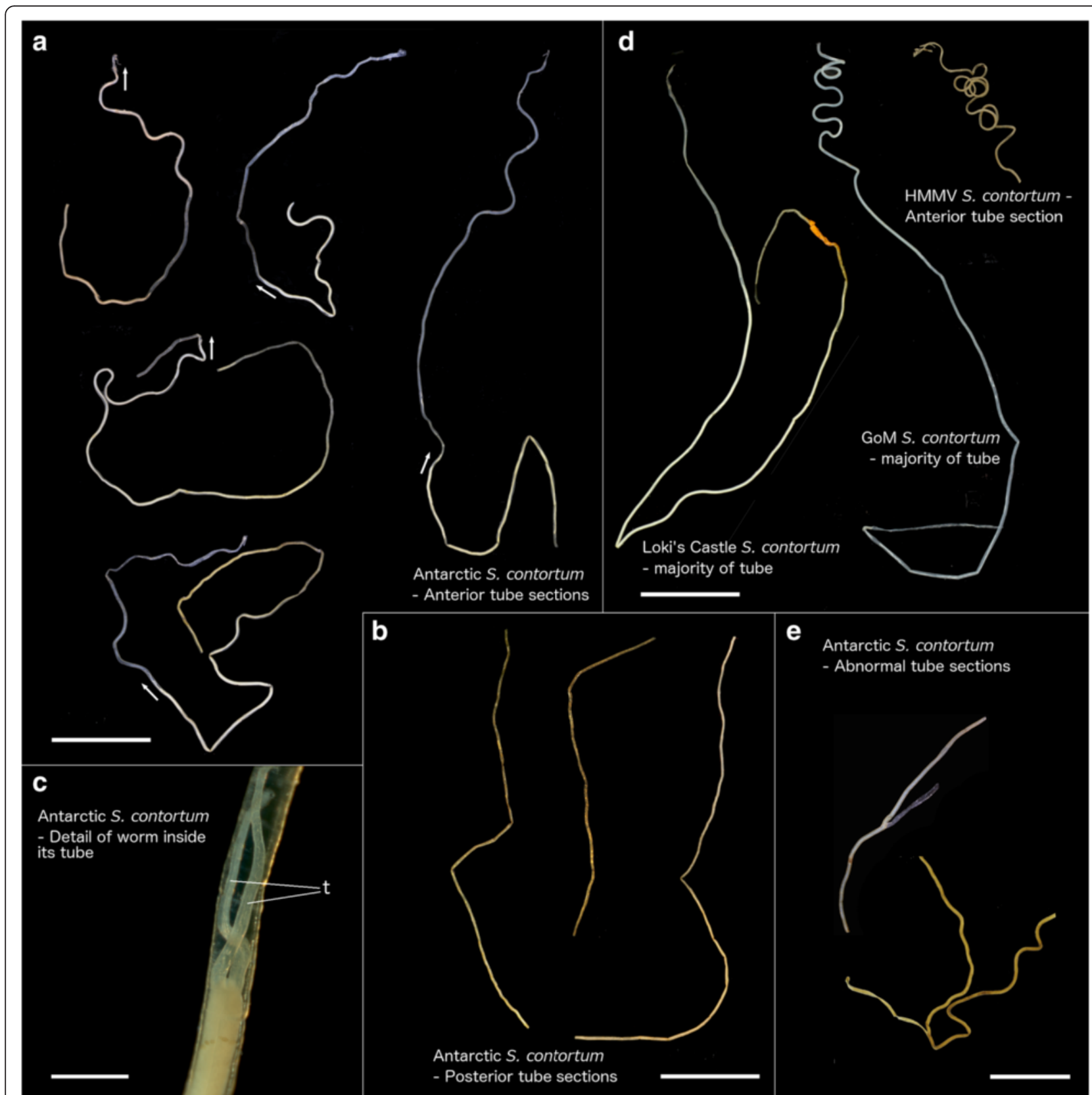

Fig. 2 Broad morphology of Sclerolinum contortum tubes. a Antarctic S. contortum anterior tube sections, arrows indicate position and orientation of the worms' heads. b Posterior sections of Antarctic S. contortum tubes. c Detail of tube with worm inside it, t - tentacles. $\mathbf{d}$ Tubes of $S$. contortum from Loki's Castle, GoM and HMMV. e Antarctic S. contortum tube sections showing abnormalities. Scale bars for (a-b, d) are $10 \mathrm{~mm}$, $400 \mu \mathrm{m}$ for (c) and $5 \mathrm{~mm}$ for (e)

Longest animal measured $52 \mathrm{~mm}$ in length (from tip of the cephalic lobe) but all were incomplete with posterior extremity missing, therefore opisthosomal characters could not be elucidated. Animals are bright red when alive, this colouration being most pronounced in trunk tissues (Fig. 3e-f). Two tentacles (Fig. 2c) often slightly different in length in individuals, tentacle lengths overall varied greatly between measured worms, from 0.83 to $3.00 \mathrm{~mm}$. Tentacles smooth or occasionally wrinkled on inner surfaces, longitudinal blood vessels visible within them (Fig. 4a-b). Dense epidermal glands occur around the base of tentacles, which are more scattered distally (Fig. 4a-b). Diameter of forepart ranges between 0.15 to $0.23 \mathrm{~mm}$. Cephalic lobe had a small, rounded triangular tip 55 to $75 \mu \mathrm{m}$ in length that protrudes from forepart (Figs. 3h and 4b). Dorsal furrow deep and wide, extending from base of tentacles (Figs. 3i and $4 \mathrm{a}$ ). Frenulum positioned 0.13 to $0.37 \mu \mathrm{m}$ from tip 


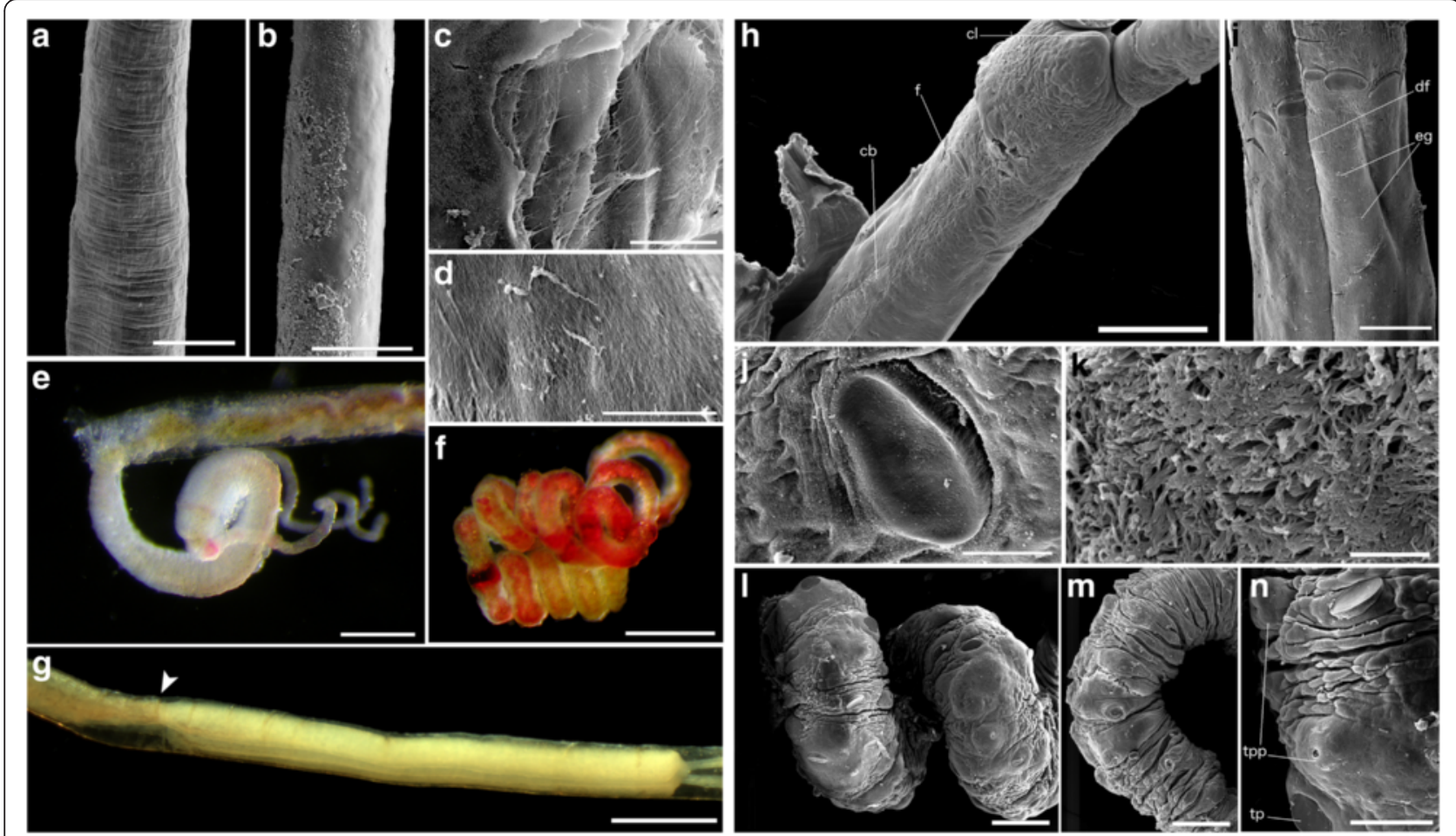

Fig. 3 Details of tubes and tissues of Antarctic Sclerolinum contortum. a Anterior section of tube showing more pronounced transverse wrinkles and faint longitudinal wrinkles, scale bar is $200 \mu \mathrm{m}$. $\mathbf{b}$ Posterior section of tube showing a smooth tube wall with attached sediment, scale bar is $200 \mu \mathrm{m}$. c Detail of tube wall showing its multi-layered, fibrous structure, scale bar is $10 \mu \mathrm{m}$. $\mathbf{d}$ Detail of tube wall interior, scale bar is $5 \mu$ m. e Anterior portion of a live worm, scale bar is $300 \mu \mathrm{m}$. f Trunk tissue of a live worm, scale bar is $500 \mu \mathrm{m}$. $\mathbf{g}$ Anterior portion of a worm showing the transition between the forepart and trunk (arrow), scale bar is $500 \mu \mathrm{m}$. $\mathbf{h}$ The anterior of a worm in ventral view, scale bar is $100 \mu \mathrm{m}$. $\mathbf{i}$ Detail of the frenulum and surrounding gland openings, dorsal view. Scale bar is $50 \mu \mathrm{m}$. $\mathbf{j}$ Detail of a frenular plaque, scale bar is $10 \mu \mathrm{m}$. $\mathbf{k}$ Detail of the ventral ciliary field, scale bar is $5 \mu \mathrm{m}$. I-n Trunk tissues of a worm, scale bars in (I-m) are $100 \mu \mathrm{m}$ and $50 \mu \mathrm{m}$ in (n). cb - ciliated band; cl - cephalic lobe; df - dorsal furrow; eg - epidermal glands; f - frenulum; tp - trunk plaque; tpp - trunk papillae

of cephalic lobe. Region surrounding frenulum shows dense covering of glands, present on both dorsal and ventral surfaces. Frenulum comprised of 9-19 oval to elongated plaques measuring 14 to $46 \mu \mathrm{m}$ in diameter (Fig. 3j), occurring as a slightly sparse or dense row. Frenular plaques occur dorsolaterally and ventrally with middle ventral plaque often missing, plaques in middle ventral and middle dorsal areas often smaller (Figs. 3h-i and $4 \mathrm{a}-\mathrm{b})$. Densely ciliated band present posterior to frenulum on ventral side of animal, that widens with increasing distance from frenulum (Figs. $3 \mathrm{~h}, \mathrm{k}$ and $4 \mathrm{~b}$ ). Region posterior to frenulum and around the ciliated band contains scattered glands, visible as slits in SEM images (Fig. 3i).

Transition between ending of dorsal furrow and beginning of a narrower, highly wrinkled and densely papillated trunk region clearly distinguished anterior and posterior zones of Antarctic S. contortum animals (Fig. 3g), with this forepart region measuring 1.7 to $4.8 \mu \mathrm{m}$ in length from the tip of the cephalic lobe to the beginning of the trunk. The trunk (Figs. 3l-n and 4c) comprised much of length of animals and was characterised by the presence of scattered oval plaques positioned on top of papillae (Fig. 3l-n). Large papillae without plaques, possibly openings of pyriform glands, also present in trunk region (Fig. 3n).

\section{Remarks}

The conspecificity of Antarctic Sclerolinum with HMMV, Loki's Castle and GoM S. contortum is strongly supported by genetic data (see later). S. contortum (from HMMV) was originally distinguished from all other species in this genus based on its long opisthosoma with few segments, and a strongly twisted anterior tube region [25]. The anterior regions of tubes from the Antarctic however lack the characteristic prominent, knot-like contortions that lend $S$. contortum its name, being instead only faintly wavy. These contortions are also absent in some of the Loki's Castle specimens (Fig. 2d). In addition, the GoM population shows that $S$. contortum opisthosoma can be longer than those of Sclerolinum magdalenae [26] and possess a similar number of segments. Hence we do not believe the wavy nature of the tube and the length of the ophisthosome are useful characters to delineate species. $S$. magdalenae also has a similar frenulum to S. contortum, 

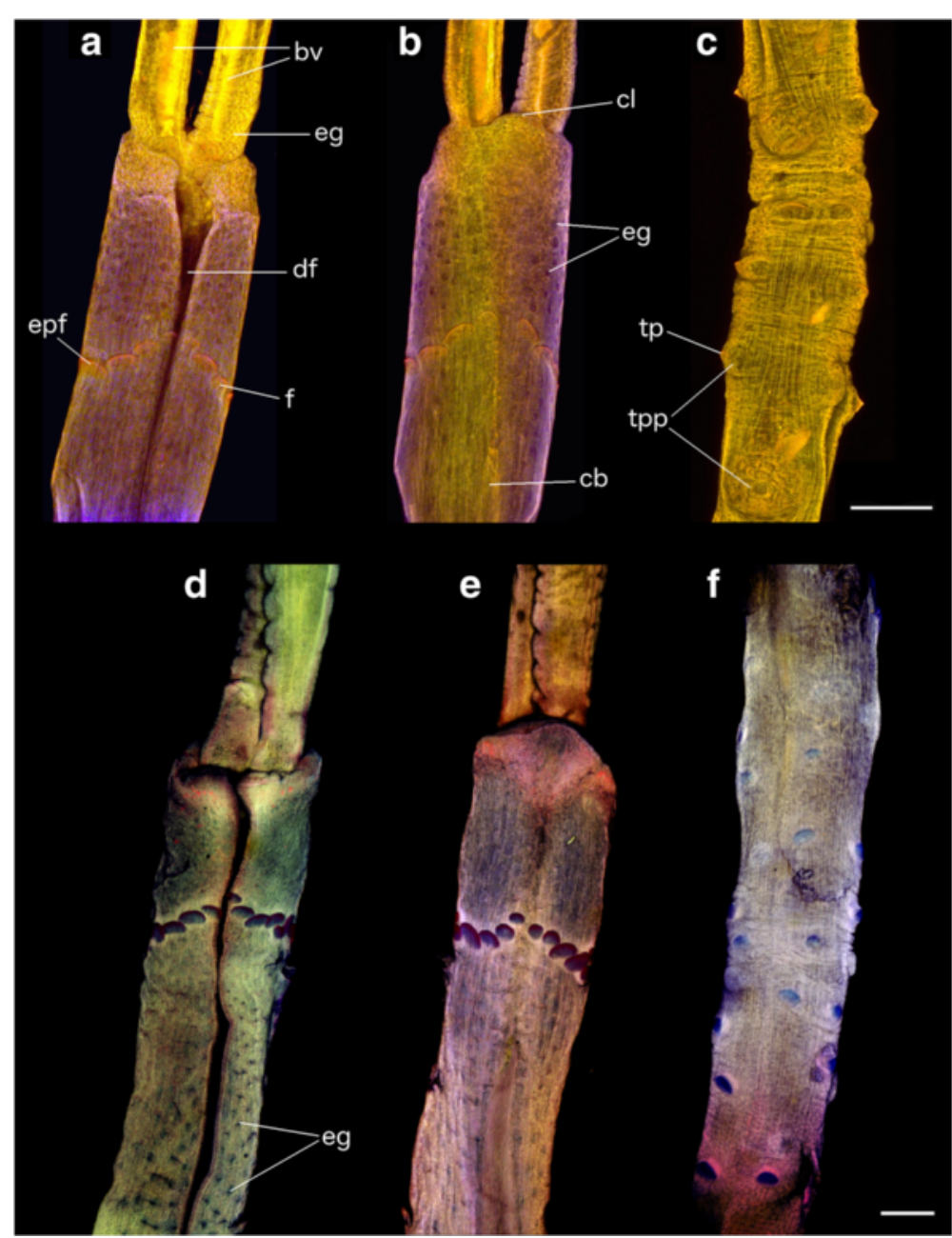

Fig. 4 Confocal laser scanning microscopy images of Sclerolinum contortum. a-c show Antarctic S. contortum, and (d-f) show S. contortum from Loki's Castle. a, $\mathbf{d}$ anterior section, dorsal view; (b, e) anterior section, ventral view; $(\mathbf{c}, \mathbf{f})$ - portion of trunk. All scale bars are $100 \mu \mathrm{m}$. bv - blood vessels; cb - ciliated band; $\mathrm{cl}$ - cephalic lobe; $\mathrm{df}$ - dorsal furrow; eg - epidermal glands; epf - elongated plaque of frenulum; $f$ - frenulum; tp - trunk plaque; tpp - trunk papillae

making these two species difficult to distinguish based on currently used characters. This raises the question of whether S. magdalenae may be the same species as $S$. contortum and thereby represent yet a further example of the wide range of this species; molecular analyses on S. magdalenae would be needed to clarify this.

Antarctic S. contortum most closely resembles the HMMV population in terms of size (diameter of tube and animal, forepart length, frenular plaque size and number; Additional file 1: Table S1). Although animals from the various populations show broad similarity (Fig. 4) [25, 27], this species is known to show pronounced morphological plasticity of its soft tissues [27] and incorporating data from the Antarctic and Loki's Castle extends the ranges of taxonomic characters for this species even further (Additional file 1: Table S1).
Ultrastructurally, tubes do not vary much between the Arctic, GoM and Antarctic populations and all exhibit both transverse and longitudinal wrinkles, while the tube abnormalities pictured in Fig. 2e are similar to those recorded for Sclerolinum brattstromi, Siboglinum ekmani and Siboglinum fiordicum [50].

\section{Ecology}

Living animals were most abundant at Hook Ridge Site 1 , where S. contortum has been reported at high densities (up to 800 individuals $\mathrm{m}^{-2}$ [30]), and tube fragments with tissue were also abundant at Hook Ridge Site 2. However, the distribution of S. contortum at Hook Ridge appears to be patchy as one of the megacore samples contained only a single specimen with a head, while another contained 71 individuals [51]. Worm specimens 
were not visible within the megacore tubes until the samples were processed, suggesting that the majority of the tubes were buried within sediments. The posterior ends of the tubes were recorded as occurring at $15 \mathrm{~cm}$ depth by Sahling et al. [30], where temperatures are approximately $20{ }^{\circ} \mathrm{C}$ and hydrogen sulphide concentrations reach $150 \mu \mathrm{m} \mathrm{L}^{-1}$, increasing at greater depths [34]. No temperature anomalies were observed in any sediments during sampling in 2011 [34]. A fully oxic water column, and oxygen penetration to depths of $2-5 \mathrm{~cm}$ into the sediment [34] require little of the tubes to project above the sediment. Sclerolinum is not reported from parts of the Hook Ridge where temperatures reach $49^{\circ} \mathrm{C}$ and siliceous crusts form over the sediments [52]. SHRIMP (Seafloor High Resolution Imaging Platform) images (Fig. 5) in the vicinity of Hook Ridge Site 1 give an indication of the habitat of this species. Diffuse hydrothermal flow in this area is evidenced through the presence of what are inferred to be patchy bacterial mats (white patches in Fig. 5a). These mats also occurred around vent chimneys present at this site (Fig. $5 \mathrm{~b}$ ) the activity of which is unknown but again no temperature anomaly was observed within what appeared to be shimmering water emanating from the chimney structure [45].

\section{Sclerolinum sp. Southward, 1961}

(Fig. 6)

\section{Material examined}

Kemp Caldera, $59.6948^{\circ} \mathrm{S} 28.35^{\circ} \mathrm{W}, 1432 \mathrm{~m}$ depth: JC55_106, lump of sulphurous material attached to sampling gear with embedded tubes. Ninety-one tube fragments removed from lump, and 4 possible tissue fragments removed from tubes and preserved separately [NHMUK 2015.1159-1166].

\section{Description}

Tubes clustered and tightly embedded into upper surface of sulphurous material (Fig. 6a), $0.23-0.34 \mathrm{~mm}$ in diameter $(n=10)$ and with a tube wall thickness of approximately $30 \mu \mathrm{m}$. Wavy to near straight in appearance. Outer tube surfaces exhibit prominent, irregular transverse wrinkles and faint longitudinal wrinkles (Fig. 6b). Tube walls are multi-layered and fibrous, and in some cases have a very rough appearance due to fragmentation of outer tube layers. SEM and EDS (energy dispersive $\mathrm{x}$-ray spectroscopy) of the surface of the sulphurous lump shows large crystalline sulphur grains within a silica matrix (Fig. 6c). When mapped in thin section, sulphur and silica show some zonation but also many sulphur grains incorporated into areas of silica (Fig. 6d). Sclerolinum tubes are rooted beneath the surface of the sulphur lump, Fig. 6e shows detail of the sulphurous material with one of the embedded tubes.

\section{Remarks}

These tubes show very similar overall and detailed morphology to those made by Sclerolinum contortum from Hook Ridge, and it is very likely that they were therefore made by this species, however as no intact animals were found (unidentifiable tissue was present) it was not possible to confirm this. The significant lengths of the tubes (Fig. 6a) suggest that the colony may have reached maturity, however the absence of good quality animal tissue, the inability to DNA sequence tube contents, and the rough appearance of some of the tube walls suggest that the colony had started degrading and that conditions may have become unfavourable for Sclerolinum. The sulphur chunk also demonstrates a pathway through which Sclerolinum tubes may fossilise, preserved

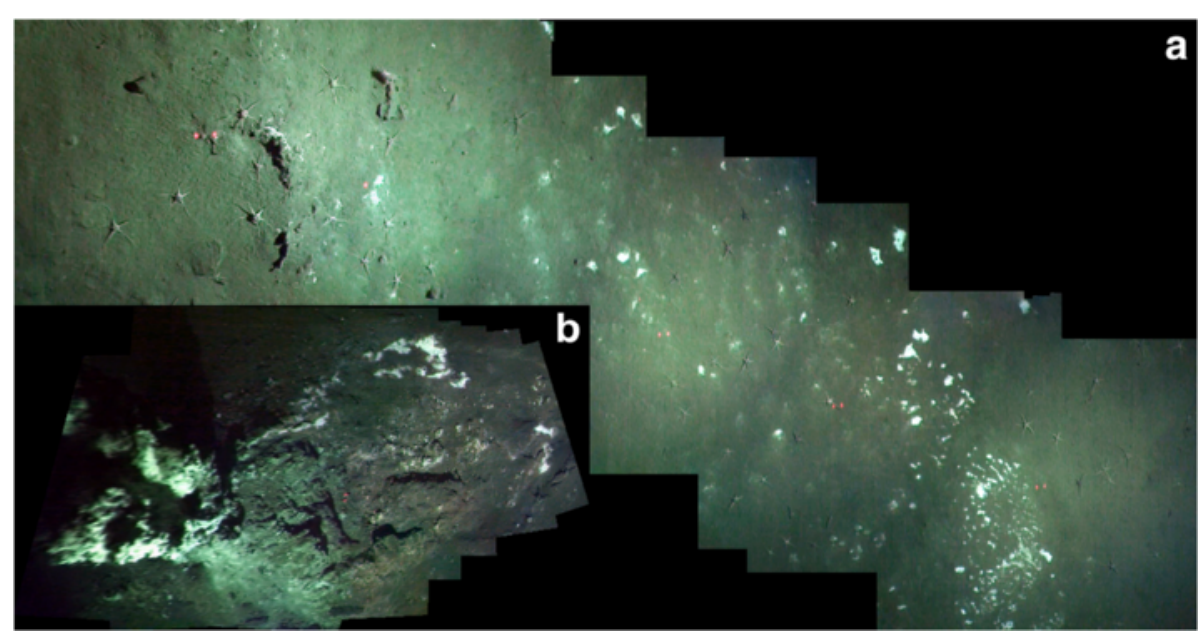

Fig. 5 SHRIMP images of Hook Ridge, Southern Ocean. Images were taken near to where megacore samples containing the highest density of Sclerolinum contortum were collected (maximum of $20 \mathrm{~m}$ distance). a Soft sediment with bacterial mats, (b) vent chimney of unknown activity with associated bacterial mats 

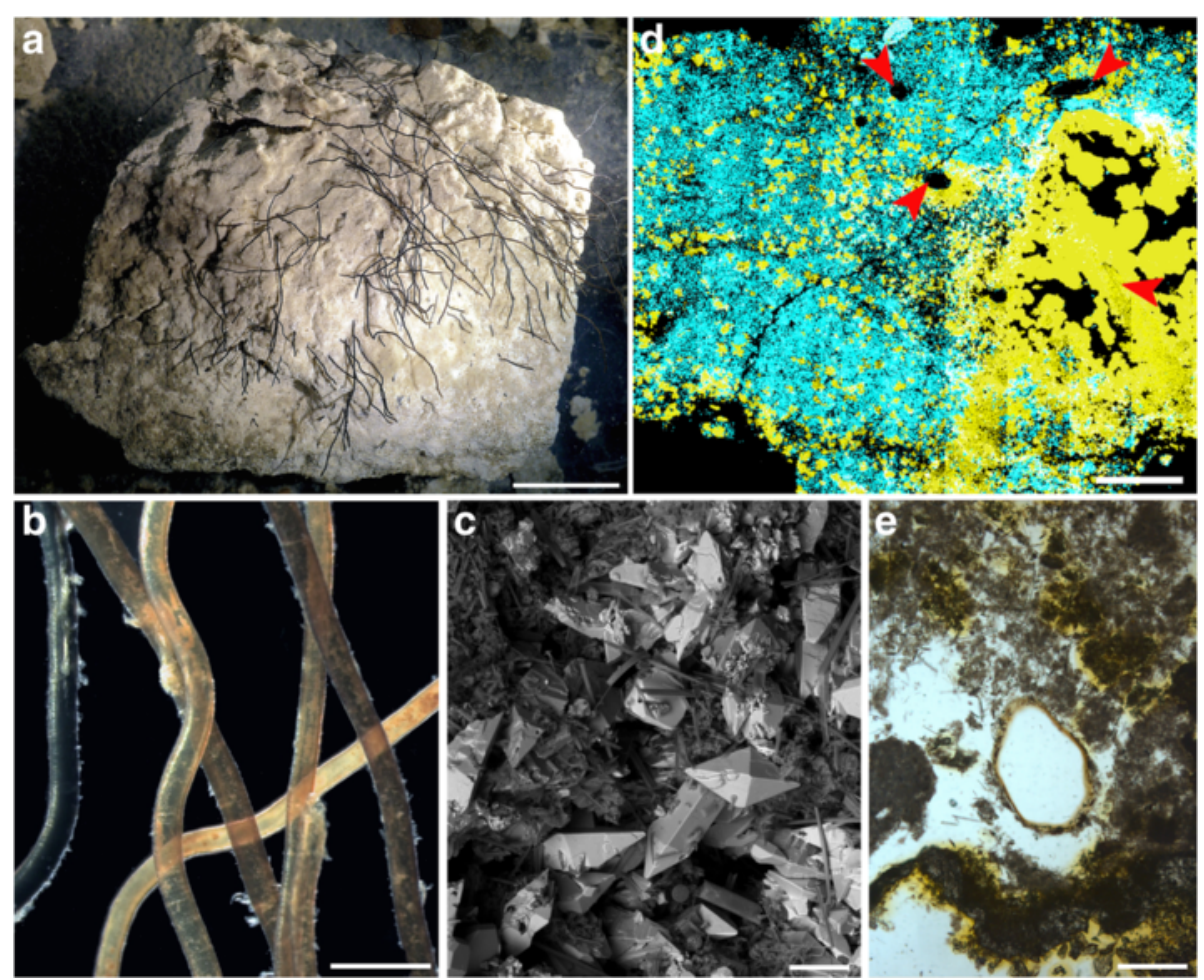

Fig. 6 Sulphurous lump with embedded Sclerolinum tubes collected from Kemp Caldera. a Sulphurous lump with embedded Sclerolinum tubes collected from Kemp Caldera, scale bar is $30 \mathrm{~mm}$. $\mathbf{b}$ Detail of the tubes embedded in the sulphurous lump pictured in (a), scale bar is $1 \mathrm{~mm}$. $\mathbf{c}$ SEM image of the surface of subsample of the sulphurous lump, scale bar is $50 \mu \mathrm{m}$. The bright crystals in this image showed a large sulphur peak when examined using energy dispersive x-ray spectroscopy (EDS). $\mathbf{d}$ EDS elemental map of sulphur lump subsample, yellow colours highlight the distribution of sulphur, blue of silicon. Red arrows show Sclerolinum tubes in section, scale bar is $2 \mathrm{~mm}$. e Detail of Sclerolinum tube section that is embedded within the sulphurous lump, scale bar is $200 \mu \mathrm{m}$

as Sclerolinum tube-shaped voids within its matrix (Fig. 6d).

\section{Ecology}

Areas of diffuse venting within Kemp Caldera would be favourable habitats for Sclerolinum, however the occurrence of these animals within such a highly acidic environment, within a substrate composed largely of sulphur has not previously been observed.

\section{Phylogeny and genetic diversity of S. contortum}

The three combined molecular analysis runs for the family Siboglinidae converged on the same tree topology and near identical posterior probability values (maximum variation of $4 \%$ ). The $50 \%$ majority rule consensus tree (Fig. 7) indicated overall strong branch support for the monophyly of the major clades of Vestimentifera, Sclerolinum, Osedax and Frenulata. Antarctic Sclerolinum falls within a clade comprised of S. contortum from GoM and the Arctic, where GoM worms form a sister group to $S$. contortum from the Arctic and Antarctic Sclerolinum, with strong branch support. However, support for the sister relationship between Antarctic
Sclerolinum and Arctic S. contortum is weaker. $18 \mathrm{~S}$ was identical between Sclerolinum brattstromi, HMMV S. contortum, and Antarctic Sclerolinum, whereas for 16S, one change (a transversion) was detected between Antarctic Sclerolinum, and S. contortum from GoM, Loki's Castle and HMMV (S. brattstromi $16 \mathrm{~S}$ was very different). COI K2P (Kimura 2 Parameter) and ' $p$ ' distances within the Sclerolinum clade varied from $0 \%$ between $S$. contortum populations, to $1.4 \%$ between $S$. contortum and Antarctic Sclerolinum, and were almost an order of magnitude greater between these taxa and $S$. brattstromi where the minimum distance detected was $8.8 \%$ (Additional file 2: Table S2). Within the $S$. contortum clade, the lowest genetic distances occurred between Loki's Castle and HMMV populations, and the greatest between the Arctic and Antarctic populations (Additional file 2: Table S2).

The phylogenetic and haplotype analyses based on 65 S. contortum COI sequences showed 14 distinct haplotypes (Fig. 8; Table 1; maximum variation of $3 \%$ for posterior probability values within the phylogenetic analysis). The number of haplotypes within the Arctic and GoM populations were greater than within the Antarctic population, in which all 27 individuals form a single haplotype 


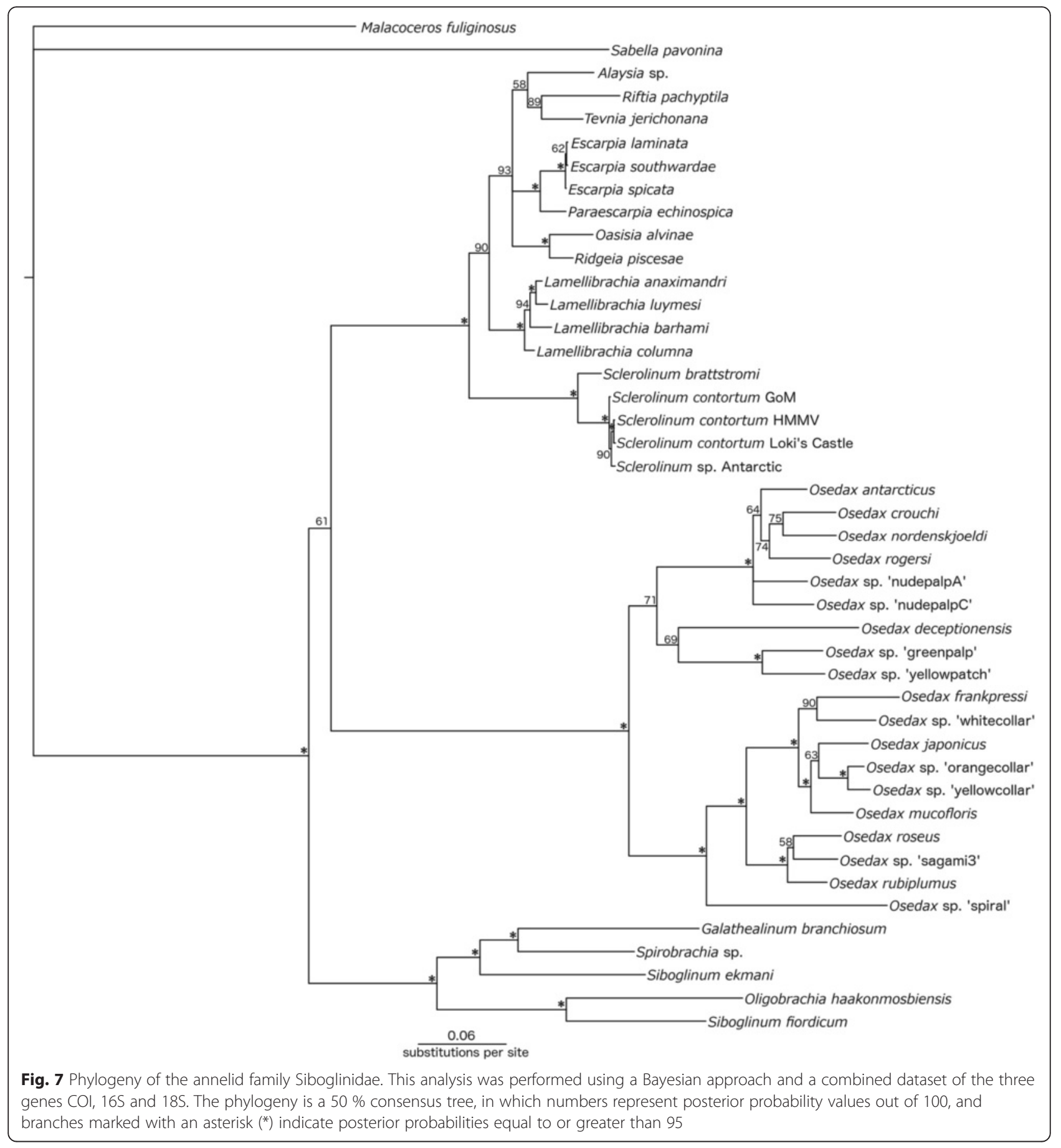

despite having the largest sample size. An HMMV individual fell within the same haplotype as Loki's Castle worms, and as genetic distances were lowest between these two populations (Additional file 2: Table S2), HMMV and Loki's Castle sequences were henceforth pooled into a single Arctic population. Nucleotide diversity $(\pi)$ and mean K2P distances within populations were on the whole low, and a non-synonymous substitution was found within the Arctic population (Table 1). The results of the analysis of molecular variance (AMOVA) (Table 2) show that the largest percentage of variation occurs between the three regional populations, which also resulted in a large $F_{S T}$ value, whereas within population variation is considerably lower. Pairwise $F_{S T}$ values are high, significant, and increase with distance between populations, being greatest between the Antarctic and Arctic populations and lowest between the Arctic and GoM populations. 


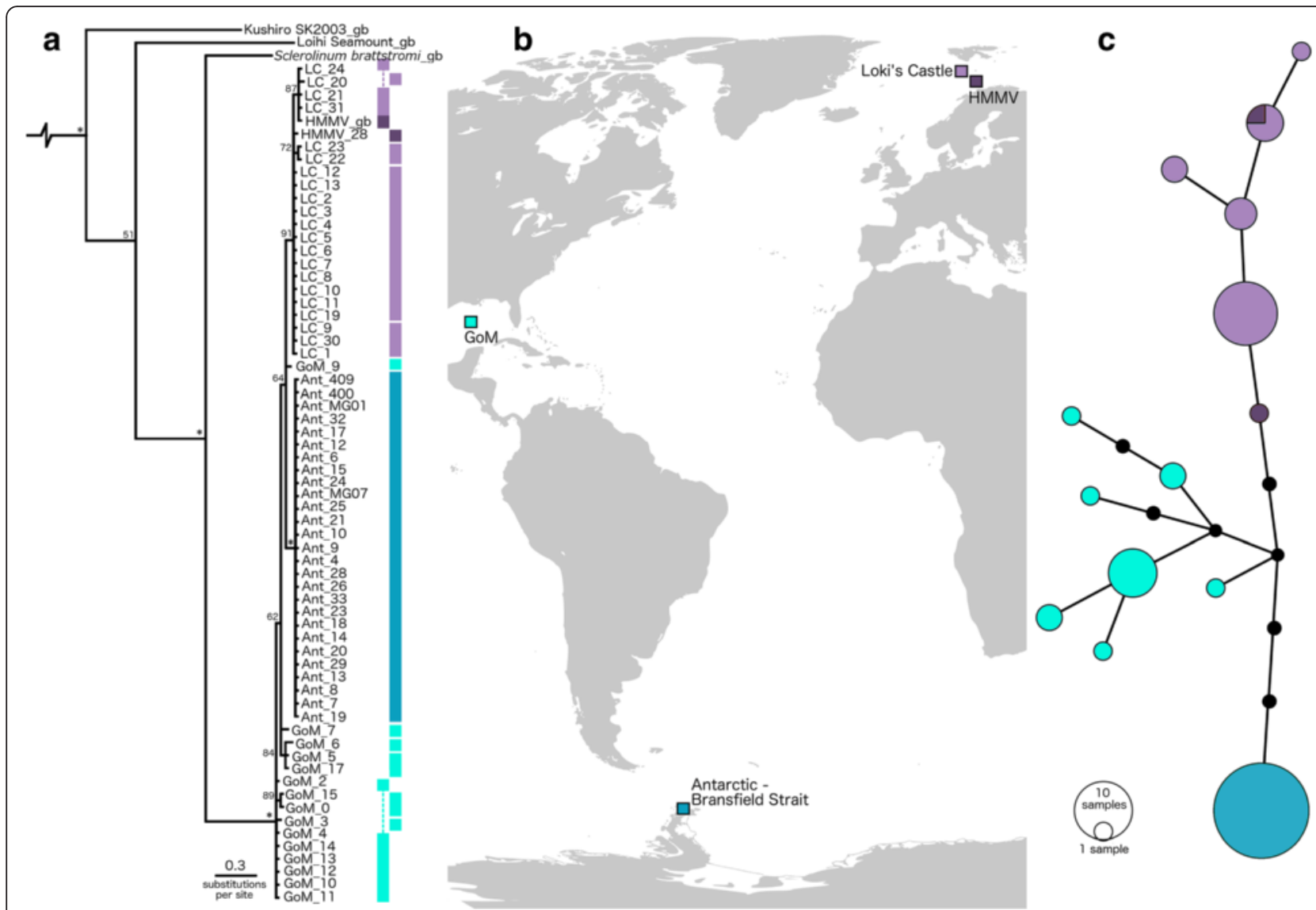

Fig. 8 Results of phylogenetic and haplotype network analyses for Sclerolinum contortum. a Phylogeny of S. contortum individuals using the COI gene with vertical bars representing haplotype groups, coloured according to population location; HMMV -dark purple, Loki's Castle (prefix LC) light purple, GoM - light blue, and the Antarctic (prefix Ant) - dark blue. The siboglinids Riftia pachyptila and Siboglinum ekmani were used as outgroups (not shown), and sequences obtained from NCBI GenBank have the suffix '_gb' (see Additional file 5: Table S4 for accession numbers). b Map of the Atlantic and part of the Southern Ocean showing the locations of the four S. contortum populations used in this study, world map source: Wikipedia. (https://en.wikipedia.org/wiki/Contemporary_history\#/media/File:WorldMap.svg). c Haplotype network constructed using the gene COI, sequenced from animals from four different S. contortum populations. Gaps were treated as missing data, and the connection limit was set to $95 \%$. Each line represents one change, and black dots represent missing haplotypes. Haplotype network was drawn using PopART (http://popart.otago.ac.nz)

\section{Discussion}

\section{First record of a bipolar siboglinid: geographic and genetic patterns}

Our data strongly supports the notion that Sclerolinum contortum is a bipolar species, with records that span almost 16,000 km from the Arctic to the Antarctic and making it the only siboglinid for which such a range has been observed. Our combined phylogenetic analysis using extended molecular data for the Sclerolinum genus demonstrates high levels of similarity of three barcoding genes COI, $16 \mathrm{~S}$ and $18 \mathrm{~S}$ between Antarctic Sclerolinum and S. contortum from the Arctic and GoM, and clearly distinguishes another Sclerolinum species (Sclerolinum brattstromi) from this group (Fig. 7). In addition, the

Table 1 Measures of COI sequence variation within S. contortum populations

\begin{tabular}{llllllll}
\hline Locality & $N$ & $\begin{array}{l}\text { No. of } \\
\text { haplo-types }\end{array}$ & $\begin{array}{l}\text { Haplotype } \\
\text { diversity (h) }\end{array}$ & $\begin{array}{l}\text { Nucleotide } \\
\text { diversity }(\pi)\end{array}$ & $\begin{array}{l}\text { No. of polymorphic } \\
\text { sites (S) }\end{array}$ & $\begin{array}{l}\text { No. of synonymous/ } \\
\text { non-synonymous substitutions }\end{array}$ & $\begin{array}{l}\text { Mean K2P } \\
\text { distance (\%) }\end{array}$ \\
\hline Arctic & 23 & 6 & $0.700 \pm 0.088$ & $0.002 \pm 0.0004$ & 5 & $4 / 1$ & 0.2 \\
GoM & 15 & 7 & $0.781 \pm 0.102$ & $0.004 \pm 0.0008$ & 10 & $10 / 0$ & 0.4 \\
Antarctic & 27 & 1 & 0 & 0 & 0 & 0 & 0 \\
Total & 65 & 14 & & & & \\
\hline
\end{tabular}


Table 2 Results of the AMOVA for the various S. contortum populations

\begin{tabular}{lllll}
\hline Source of variation & Degrees of freedom & Sum of Squares & Variance components & Percentage of variation \\
\hline Among populations & 2 & 102.573 & $2.41055 \mathrm{Va}$ & 84.5 \\
Within populations & 62 & 27.424 & $0.44232 \mathrm{Vb}$ & 15.5 \\
Total & 64 & 129.997 & 2.85287 & \\
Fixation index $\left(F_{\text {ST }}\right)$ & 0.84496 & & \\
Pairwise F F values & & & \\
GoM & Arctic & GoM & \\
Antarctic & $\mathbf{0 . 7 2 1 1}$ & & \\
\hline
\end{tabular}

$\mathrm{F}_{\mathrm{ST}}$ values in bold are significant $(p<0.05)$

mitochondrial marker COI also differentiates an additional two Sclerolinum species from the S. contortum clade (Kushiro SK2003 and Loihi Seamount; Fig. 8). COI genetic distances are more than 6 times greater between $S$. contortum (including the Antarctic population) and $S$. brattstromi compared to within the former clade (Additional file 2: Table S2), in which divergence is well below $3 \%$, the generally accepted threshold for delimiting species $[53,54]$. The morphology of Antarctic Sclerolinum also generally fits within the variation observed for S. contortum from other areas, most closely resembling the soft tissue morphology of the most distant population, from HMMV (Additional file 1: Table S1). Classifying Antarctic Sclerolinum as S. contortum despite the great distances between populations highlights the important taxonomic observation that annelids with very similar morphology and DNA can be spread over vast geographical areas, with their distributions controlled by habitat availability and local ecology.

Bipolarity has so far been observed in only a handful of deep-sea organisms, but demonstrates that steep temperature gradients and limited water exchange between the Southern and surrounding oceans have not completely restricted the spread of deep-sea fauna across these barriers [40]. Southern Ocean vent sites such as the East Scotia Ridge differ from sites on Mid-Atlantic Ridge and East Pacific Rise in that fauna such as vestimentiferan and alvinellid polychaetes, vesicomyid clams, bathymodiolid mussels, and alvinocaridid shrimp are absent [43]. However the ability of S. contortum to have migrated across Southern Ocean dispersal barriers suggests that the absence of vestimentiferans at Antarctic vent sites may not be the result of historical dispersal limitation (vicariance). The extensive, bipolar nature of this deep-sea chemosynthetic tubeworm also accentuates that being widespread in the deep-sea is a real and common pattern, with examples supported by molecular data emerging from a variety of additional taxa in recent years $[8,55-58]$.

Although our data support $S$. contortum conspecificity across the Arctic, GoM and Antarctic, at a population level there is evidence that distance is a barrier to gene flow. While mixing appears to occur between the HMMV and Loki's Castle populations that are separated by approximately $270 \mathrm{~km}$ (Fig. 8), this does not seem to be the case between the Arctic, GoM and Antarctic. Though these three regional populations show very high genetic similarity, the structure presented by the COI haplotype network (Fig. 8), and the $F_{\mathrm{ST}}$ values obtained for population pairs (Table 2), suggest that geographic distance does present a barrier to gene flow for this species. This is largely consistent with research into the connectivity of hydrothermal vent vestimentiferans on the EPR, where for both Riftia pachyptila and Tevnia jerichonana there appears to be little gene flow between the most distant populations of these species [20, 21]. Pairwise $F_{\mathrm{ST}}$ values between the most distant populations of these two species are similar to those reported for $S$. contortum in this study, however it is obvious that many populations of $S$. contortum are likely to exist between those sampled in this study, and sampling gaps have been found to inflate $F_{\mathrm{ST}}$ [59].

High genetic correspondence with lack of gene flow over large distances is also characteristic of Escarpia spp., species of which show high levels of similarity in the mitochondrial genes $16 \mathrm{~S}, \mathrm{COI}$ and cytochrome $b$, but can be differentiated on their morphology, as well as by using a nuclear gene (haemoglobin subunit B2 intron) and microsatellite markers [22]. Our interpretation of geographically distant Sclerolinum populations belonging to one species contrasts with the division of Escarpia into three separate species despite their genetic similarity, however we believe our classification to be justified based on the reasons outlined above, and recommend greater caution in describing genetically-similar but geographically distant populations of siboglinids as new species based on morphology.

Despite the evidence for low gene flow at regional scales, Sclerolinum contortum has managed to spread to both poles as well as subtropical latitudes, and the question remains as to how this was achieved. Nothing is presently known of the larvae of Sclerolinum, but when the larvae of the vestimentiferan Riftia pachyptila are considered, which can disperse $100 \mathrm{~km}$ along the EPR ridge axis [60], it is unlikely that $S$. contortum larvae 
travelled the $\sim 10,000 \mathrm{~km}$ between the GoM and Hook Ridge in a single journey. As S. contortum appears to be capable of colonising a large range of substrates, dispersal over wide areas through the use of a variety of chemosynthetic habitats as 'stepping stones' [61, 62] might be the most plausible explanation for this species. Such a hypothesis may be supported by our results which show that there is greater genetic similarity between the spatially closer Arctic and GoM populations, and GoM and Antarctic populations, than there is between the two polar populations (Arctic and Antarctic; Table 2). However, the presently known number of $S$. contortum populations is too low to conduct a test for the above scenario, therefore whether this is the best model cannot be resolved at present. Stepping-stone dispersal would suggest that $S$. contortum is more widespread than currently supposed, which does appear to be the case in the Antarctic. The large mass of tubes recovered from Kemp Caldera suggests that S. contortum populations come and go, taking advantage of reducing conditions where they are encountered and dying out when these temporary oases dry up.

Such a lifestyle may also explain the low COI haplotype diversity observed within the Antarctic population in comparison to the Arctic and GoM worms used for this study. The Antarctic population may be demonstrating the effects either of a founder event or bottleneck [63], where a founder effect may arise as a result of a number of opportunistic S. contortum individuals finding suitable conditions and settling at Hook Ridge, and persisting in the sustained diffuse hydrothermal flow at this site. However, the ephemeral nature of hydrothermal circulation within the Bransfield Strait [45], and repeated glacial-interglacial events affecting the Southern Ocean mean that it may also be plausible for the Antarctic $S$. contortum population to have undergone a bottleneck (loss of genetic diversity following a population crash) [64]. Evidence of a genetic bottleneck linked to glacial cycles has been detected for a number of Antarctic species (see [65] for a review), and ultimately more samples from a wider area of the Southern Ocean would be required to test this in S. contortum. Sclerolinum has also been shown to be capable of asexual reproduction via breaking and regenerating missing ends $[66,67]$, which may also account for the low genetic diversity of the Antarctic population.

There is currently no fossil record for Sclerolinum. As well as demonstrating a pathway through which Sclerolinum tubes may become preserved in the fossil record, this study shows that any future reports of Sclerolinum fossil discovery should be mindful of the following: fossils found in a range of ancient chemosynthetic environments, from very distant parts of the world, and exhibiting varying degrees of tube contortion may belong to the same species. Recent reports of Cretaceous Osedax fossils [68] imply that Siboglinidae has more ancient origins than indicated by molecular clock estimates [69-71], suggesting that the widespread distribution, morphological and habitat plasticity exhibited by Sclerolinum may have contributed to the survival of this genus over long evolutionary timescales too [72].

\section{Natural history of S. contortum in the Southern Ocean}

We have shown that $S$. contortum can exhibit even greater morphological plasticity than was previously noted for this species by Eichinger et al. [27]. Much of this plasticity is in the tubes constructed by this worm after which the species is named. Tube morphology may be a condition that is dictated by environmental factors, as has previously been shown for the highly plastic tubes built by the vent dwelling vestimentiferan Ridgeia piscesae [73]. Environmental factors can also influence the physiology of these worms, thereby affecting their genetic diversity [74]. While environmental parameters were not measured by the present study, we speculate that contortion of the anterior of S. contortum tubes increases their surface area to volume ratio, thus improving the efficiency of oxygen uptake and may therefore result from settlement in lower oxygen conditions.

The obvious morphological plasticity of Sclerolinum contortum is matched by its remarkable ecological and habitat plasticity. With our new data from the Antarctic we can now show that it is able to colonise a vast range of chemosynthetic habitats including high-temperature acidic white smoker vent fields, low-temperature sedimented diffuse vent fields, hydrocarbon cold seeps and mud volcanoes. Chemosynthetic invertebrates have been likened to terrestrial weeds [75] in virtue of their ability to colonise ephemeral/disturbed environments, as well as their effective dispersal, rapid growth rates, and early reproduction [76, 77], and in this sense, we can also think of $S$. contortum as a 'chemosynthetic weed' due to its ability to quickly populate a wide range of sulphurrich habitats and spread over great distances.

Weedy species can have a dramatic influence on the environments they colonise. Their impacts are welldocumented particularly in reference to terrestrial nonnative species, and have demonstrated the ability of weedy species to have pronounced ecosystem, community and population-level effects [78, 79]. Supporting the concept of the Sclerolinum weed is the observation that the species can have a considerable influence on the biogeochemistry of the sediment at the sediment-hosted Bransfield hydrothermal vents [34]. Along with the maldanid Nicomache lokii, S. contortum forms a complex three-dimensional habitat for free-living invertebrates at Loki's Castle [38], as well as in the Nyegga seep area of the Storegga Slide where filamentous bacteria cover $S$. 
contortum tube surfaces, thereby also providing substrate and food for associated organisms [35]. S. contortum therefore represents an important keystone species within the range of reducing environments it inhabits.

\section{Conclusions}

Since their initial discovery alongside hydrothermal vent chimneys in the late 1970s, siboglinid worms have continued to surprise and amaze with their unusual adaptations to a mode of life in the deep sea dependant solely on endosymbionts. By investigating in detail the DNA, morphology and a novel inhabiting substrate of the very poorly studied Sclerolinum genus, the present study has found that they too conform to this pattern, by possessing extraordinary morphological and ecological plasticity that has allowed them to occupy a remarkable range that spans across all of the world's oceans. However, fundamental knowledge of the biology of these worms is still lacking - there is presently no information on Sclerolinum reproduction, larvae and their dispersal, and symbionts from the range of chemosynthetic environments which this genus occupies. We therefore suggest these areas as potential directions for future research into this group.

\section{Methods}

\section{Sample collection}

Antarctic sample collection was conducted on board RRS James Cook expedition JC55 during JanuaryFebruary 2011 (Table 3), during which Sclerolinum was collected from two locations: Hook Ridge, Bransfield Strait, and Kemp Caldera. At Hook Ridge, venting occurs through sediment as low temperature discharge of phase-separated fluids that are highly diluted by seawater [45]. At Kemp Caldera, both hot and diffuse venting has been found that is characterised by unusual, highly acidic and sulphidic fluid composition. At a site named 'Winter Palace', crumbly chimneys release white smoker-type hydrothermal fluids up to $212{ }^{\circ} \mathrm{C}$, while at 'Great Wall' a seafloor fissure releases low temperature diffuse fluids from which sulphur-rich minerals precipitate [80] [Copley et al. in prep.].

Samples were obtained using a Bowers \& Connelly megacorer fitted with multiple $10 \mathrm{~cm}$-diameter polycarbonate core tubes. Sclerolinum sp. tubes containing animal tissues and empty Sclerolinum sp. tubes were collected from two Hook Ridge sites, Hook Ridge Site 1 and Hook Ridge Site 2 (Fig. 1; Table 3). Sclerolinum sp. tubes from Kemp Caldera were acquired using a gravity corer, to which a sulphurous lump containing embedded tubes had become attached. Possible Siboglinidae tube fragments were collected from The Axe and Bransfield Off-vent, the latter comprising a non-active site located approximately $21 \mathrm{~km}$ south of the Hook Ridge sites. Samples were preserved in $80 \%$ ethanol or $6 \%$ formalin on board the ship. SHRIMP was used to visualise the seabed within a $20 \mathrm{~m}$ radius of Hook Ridge Site 1. S. contortum specimens from Loki's Castle and HMMV, Arctic Ocean, and the GoM (Additional file 3: Methods supplement) were used for morphological and genetic comparisons with Antarctic Sclerolinum sp. (Table 3).

\section{Morphological and compositional analyses}

Taxonomic characters were measured in 10 Antarctic and 10 Loki's Castle worms. Unfortunately no complete animals were found, therefore only characters of the anterior and trunk regions of the worms were recorded. Tubes were either cut around sections of the worms, or they were visualised through their tubes using a ZEISS Discovery V.20 stereomicroscope. Measurements were performed using ZEISS AxioVision digital processing software as well as Image (version 1.46r). To visualise taxonomic characters more clearly, sections of Antarctic and Loki's Castle worms were cut out of their tubes, and imaged using laser-induced autofluorescence within a Nikon A1-Si Confocal microscope at the Natural History Museum, UK (NHM), operated in spectral imaging mode. In addition, the forepart and trunk regions of a Sclerolinum sp. worm fragment from the Antarctic were critical-point dried, coated in gold-paladium, and imaged

Table 3 Collection details of Siboglinidae specimens examined within this study

\begin{tabular}{|c|c|c|c|c|c|c|}
\hline Locality & Taxon & Site & Latitude & Longitude & Depth (m) & No. of tube fragments* \\
\hline \multirow[t]{3}{*}{ Antarctic } & Sclerolinum sp. & Hook Ridge Site 1 & -62.1969 & -57.2975 & 1174 & $686^{*}$ \\
\hline & & Hook Ridge Site 2 & -62.1924 & -57.2783 & 1054 & $87^{*}$ \\
\hline & & Kemp Caldera & -59.6948 & -28.35 & 1432 & $95^{*}$ \\
\hline \multirow[t]{4}{*}{ Arctic } & S. contortum & Loki's Castle CG2009 & 73.5662 & 8.1585 & 2357 & $33^{*}$ \\
\hline & & Loki's Castle CG2008 & $73.5662-73.5683$ & $8.1585-8.1563$ & - & $8^{*}$ \\
\hline & & HMMV CG2010 & 71.9975-71.9999 & $14.7329-14.7316$ & 1262 & $1^{*}$ \\
\hline & & HMMV VICKING 2006 & 72.0013 & 14.7225 & 1270 & $50+$ \\
\hline GoM & S. contortum & Walker Ridge WR269 & 26.6833 & -91.65 & 1954 & $21^{*}$ \\
\hline
\end{tabular}

Asterisk $*^{*}$ ) denotes samples within which a subset of the tube fragments contained animal tissues 
using a secondary electron detector within a FEI Quanta 650 FEG-ESEM (NHM).

A subsection of the sulphurous lump with embedded Sclerolinum sp. tubes (recovered from Kemp Caldera, Southern Ocean) was viewed within a LEO 1455VP SEM (at the NHM), and point EDS spectra were obtained from its surface within the same SEM. The subsection was then prepared into a polished thin section and its elemental composition was mapped using EDS within a Carl Zeiss Ultra Plus Field Emission SEM, also at the NHM.

\section{Phylogenetic sequencing and analyses}

Total genomic DNA was extracted from 64 Sclerolinum worm fragments: 27 Antarctic Sclerolinum sp., $15 \mathrm{~S}$. contortum from the GoM, $21 \mathrm{~S}$. contortum from Loki's Castle, and one S. contortum individual from HMMV. Worm fragments with tentacles and forepart, and long worm fragments were selected for extractions to increase the likelihood of sampling from different individuals. DNA extractions of Antarctic and GoM specimens were performed using a Hamilton Microlab STAR Robotic Workstation combined with a DNeasy kit (Qiagen, Valencia, CA). Approximately $400 \mathrm{bp}$ of the mitochondrial gene 16S, $600 \mathrm{bp}$ of the mitochondrial gene COI, and $840-1370$ bp of the nuclear $18 \mathrm{~S}$ gene were amplified (all primers used for PCRs and sequencing are listed in Additional file 4: Table S3). PCR mixtures for Antarctic and GoM specimens contained $1 \mu \mathrm{l}$ of each primer $(10 \mu \mathrm{M}), 2 \mu \mathrm{l}$ of DNA template, and $21 \mu \mathrm{l}$ of Taq PCR Master Mix (Qiagen). The PCR profile was as follows: $94{ }^{\circ} \mathrm{C} / 300 \mathrm{~s},\left(94{ }^{\circ} \mathrm{C} / 60 \mathrm{~s}, 50{ }^{\circ} \mathrm{C} / 60 \mathrm{~s}, 72{ }^{\circ} \mathrm{C} / 120 \mathrm{~s}\right) * 35 \mathrm{cy}-$ cles, $72{ }^{\circ} \mathrm{C} / 300 \mathrm{~s}$. PCR products were visualised on $1.5 \%$ agarose gels following electrophoresis, and sequenced using an Applied Biosystems 3730XL DNA Analyser at the NHM. DNA extraction and PCR of Arctic specimens (Loki's Castle and HMMV) were carried out at the Biodiversity Laboratories, University of Bergen (BDL, DNAlab section, Department of Biology) where an Applied Biosystems 3730XL DNA Analyser was used for sequencing. The PCR mixtures for amplification of $16 \mathrm{~S}$ and COI contained $1 \mu \mathrm{l}$ of each primer $(10 \mu \mathrm{M}), 1 \mu \mathrm{l}$ of DNA template, $2.5 \mu \mathrm{l}$ Qiagen CoralLoad buffer (10x), $1 \mu \mathrm{l}$ Qiagen $\mathrm{MgCl}$ $(25 \mu \mathrm{M}), 2 \mu \mathrm{l}$ dNTPs (TaKaRa; $2.5 \mu \mathrm{M}$ of each dNTP), $0.15 \mu \mathrm{l}$ TaKaRa HS taq, and $16.35 \mu \mathrm{l} \mathrm{PCR}$ water. The PCR profile for $16 \mathrm{~S}$ was as follows: $95^{\circ} \mathrm{C} / 300 \mathrm{~s},\left(95^{\circ} \mathrm{C} / 30 \mathrm{~s}\right.$, $\left.50{ }^{\circ} \mathrm{C} / 30 \mathrm{~s}, 72^{\circ} \mathrm{C} / 90 \mathrm{~s}\right) * 35$ cycles, $72{ }^{\circ} \mathrm{C} / 600 \mathrm{~s}$, while the following profile was used for COI: $95{ }^{\circ} \mathrm{C} / 300 \mathrm{~s},\left(95^{\circ} \mathrm{C} /\right.$ $\left.\left.45 \mathrm{~s}, 45{ }^{\circ} \mathrm{C} / 45 \mathrm{~s}, 72{ }^{\circ} \mathrm{C} / 60 \mathrm{~s}\right)\right)^{*} 5$ cycles, $\left(95^{\circ} \mathrm{C} / 45 \mathrm{~s}, 51{ }^{\circ} \mathrm{C} /\right.$ $\left.45 \mathrm{~s}, 72{ }^{\circ} \mathrm{C} / 60 \mathrm{~s}\right) * 35$ cycles, $72{ }^{\circ} \mathrm{C} / 600 \mathrm{~s}$. In total, $16 \mathrm{~S}$ was sequenced for 28 worm fragments, COI for 64 , and $18 \mathrm{~S}$ for two worm fragments.

Molecular phylogenetic analyses were performed using a combined dataset of $16 \mathrm{~S}, \mathrm{COI}$ and $18 \mathrm{~S}$ sequences for members of the family Siboglinidae. A total of 44 terminal taxa were included in the analyses, of which five were Sclerolinum, and 39 were from other Siboglinidae genera. For the above analyses 111 sequences were obtained from NCBI Genbank, accession numbers for which are listed in Additional file 5: Table S4. The sabellid Sabella pavonina and spionid Malacoceros fuliginosus were used as outgroup taxa, of which M. fuliginosus was used to root the tree. Outgroup choice was based on the analyses of Rousset et al. [81] and Weigert et al. [82]. Overlapping sequence fragments were concatenated into consensus sequences using Geneious [83], and aligned using the following programs (provided as plug-ins in Geneious): MUSCLE for COI [84], and MAFFT for $18 \mathrm{~S}$ and 16S [85]. The evolutionary models used for each gene were selected using jModelTest [86]. Based on the Akaike Information Criterion (AIC), the best fitting models of nucleotide substitution were TIM1 + I + G for COI and 18S, and TIM2 + G for 16S. As the model GTR $+\mathrm{I}+\mathrm{G}$ is the closest approximation of the TIM models available in MrBayes, the GTR $+\mathrm{I}+\mathrm{G}$ model was used for all three genes in the combined analysis. A Bayesian molecular phylogenetic analysis was conducted using MrBayes 3.1.2 [87]. Analyses of the combined dataset were run three times for 10,000,000 generations, with 2,500,000 generations discarded as burn-in. Genetic distances for the COI gene within the genus Sclerolinum were calculated using the K2P model, and $p$-distances were determined in MEGA 5.1 [88].

\section{Genetic diversity}

A close relationship between Antarctic Sclerolinum sp. and $S$. contortum was detected from the above investigations, therefore an additional alignment was used for a phylogenetic analysis using a total of 68 COI Sclerolinum sp. sequences (Sclerolinum brattstromi, Kushiro-SK-2003 Sclerolinum sp., Loihi Seamount Sclerolinum sp., 27 Antarctic Sclerolinum sp., 15 GoM, 21 Loki's Castle, and 2 HMMV S. contortum) for which two additional siboglinid COI sequences (Riftia pachyptila and Siboglinum ekmani) were used as outgroups. The alignment was trimmed to standardise sequence lengths, and the analysis was performed in the same way as the combined analysis outlined above. In addition, a haplotype distribution was created using only Antarctic Sclerolinum sp. and S. contortum sequences in TCS 1.21 [89] and drawn in PopART (http://popart.otago.ac.nz). Gaps were treated as missing data, and the connection limit was set to $95 \%$. There appeared to be little genetic differentiation between HMMV and Loki's Castle S. contortum therefore sequences from these localities were subsequently pooled into one Arctic population, while GoM S. contortum and Antarctic Sclerolinum sp. were treated as two additional populations. Haplotype diversity, nucleotide diversity, and number of 
polymorphic sites were calculated within each population (Arctic, GoM and Antarctic) using DnaSP 5.10.1 [90]. Average genetic distances (K2P) within each population were calculated using MEGA 5.1 [88]. Pairwise $F_{S T}$ values and an AMOVA were computed using Arlequin 3.5.1.3 [91]. The AMOVA was performed using K2P distances and 1000 permutations.

\section{Ethics statement}

Ethics approval is not required for the collection and investigation of the morphology and DNA of annelid worms. Antarctic specimens were collected under the Foreign and Commonwealth Office Antarctic permit number S5-4/2010 issued to National Marine Facilities for the JC55 research expedition. Permits were not required by the collectors of Arctic and Gulf of Mexico material.

\section{Availability of supporting data}

Morphological data supporting the results of this article are included within Additional file 1: Table S1. Occurrence data on specimens used in this study (in DarwinCore Archive format) and additional data sets (DNA sequence alignments) are available in the figshare repository (http:// dx.doi.org $/ 10.6084 / \mathrm{m} 9$.figshare.1613855). DNA sequences are available in GenBank (http://www.ncbi.nlm.nih.gov/ genbank/), with NCBI accession numbers detailed in Additional file 5: Table S4 (a sequence for each detected Sclerolinum contortum COI haplotype is available).

\section{Additional files}

Additional file 1: Table S1. Comparison of morphological characters between Antarctic Sclerolinum and three populations of S. contortum. (DOCX $100 \mathrm{~kb}$ )

Additional file 2: Table S2. P-distance (above diagonal) and K2P (below diagonal) genetic distances (in \%) among the genus, as well as putative, Sclerolinum. (DOCX $49 \mathrm{~kb})$

Additional file 3: Methods supplement. Details on the collection of additional Sclerolinum contortum specimens for comparison with Antarctic material. (DOCX $73 \mathrm{~kb}$ )

Additional file 4: Table S3. Primers used for PCR and sequencing. (DOCX $118 \mathrm{~kb}$ )

Additional file 5: Table S4. Taxa used in Bayesian molecular analyses and GenBank accession numbers. (DOCX $118 \mathrm{~kb}$ )

\footnotetext{
Abbreviations

16S: Mitochondrial large subunit ribosomal RNA; 18S: Nuclear small subunit subunit ribosomal RNA; AIC: Akaike information criterion; AMOVA: Analysis of molecular variance; COI: Cytochrome oxidase subunit I; EDS: Energy dispersive x-ray spectroscopy; EPR: East Pacific Rise; GoM: Gulf of Mexico; HMMV: Håkon Mosby Mud Volcano; K2P: Kimura 2 Parameter; MAFFT: Multiple Alignment using Fast Fourier Transform; MUSCLE: Multiple Sequence Comparison by Log-Expectation; NHM, NHMUK: Natural History Museum, United Kingdom; SHRIMP: Seafloor High Resolution Imaging Platform.
}

\section{Competing interests}

The authors declare that they have no competing interests.

\section{Authors' contributions}

MG contributed to study design, performed measurements, imaging and genetic analyses and wrote the manuscript. HW helped to design the study and with all aspects of the molecular work. JB processed JC55 cruise samples and provided SHRIMP imagery. ME performed DNA sequencing of Loki's Castle material. RM provided sulphurous chunk with embedded Sclerolinum tubes and biogeochemical components of the manuscript. $\mathrm{CL}$ helped with taphonomical observations. AG collected Antarctic S. contortum material, imaged specimens live at sea, designed the study, participated in its coordination, and helped to draft the manuscript. All authors read and approved the final manuscript.

\section{Acknowledgements}

We would like to thank the masters and crews of the NERC 'Chemosynthetically-driven ecosystems in the Southern Ocean' (ChEsSo) research cruise on RRS James Cook JC055 (Professor Paul Tyler PI), the National Oceanography Centre technicians who operated the SHRIMP and ROV Isis platforms, the University of Bergen Centre for Geobiology expeditions on RV G. O. Sars during 2008-2010, the NOAA Ronald H. Brown expedition no. RB-07-04, and the 2006 VICKING cruise on board R/V Pourquoi pas? for their help in collecting specimens used in this study. We are also especially indebted to the following scientists for their generous donations of material for use in this study: Prof. Hans Tore Rapp and Dr. Jon Anders Kongsrud for material from Loki's Castle hydrothermal vent field, Prof. Monika Bright for material from the Gulf of Mexico, and Dr. Ann Andersen for material from Håkon Mosby Mud Volcano. Thank you to Alex Ball and Tomasz Goral (NHM) for help with imaging, Laura Hepburn for guidance regarding sulphur lump analyses, and to Gabrielle Kennaway and Tony Wighton (NHM) for their help in the preparation of thin sections. Thank you also to Bob Vrijenhoek, Shannon Johnson, and two anonymous reviewers for valuable comments on this work. MG is funded by NERC CASE PhD studentship no. NE/K500847/1. JB is funded by NERC CASE PhD studentship no. NE/L501542/1. The ChEsSo programme was funded by a NERC Consortium Grant (NE/DO1249X/1) which is gratefully acknowledged.

\section{Author details}

'Life Sciences Department, Natural History Museum, London, UK. ${ }^{2}$ School of Earth and Environment, University of Leeds, Leeds, UK. ${ }^{3}$ School of Geography, University of Leeds, Leeds, UK. ${ }^{4}$ Centre for Geobiology, University of Bergen, Bergen, Norway. ${ }^{5}$ Department of Biology, University of Bergen, Bergen, Norway. ${ }^{6}$ Ocean and Earth Science, National Oceanography Centre Southampton, University of Southampton, Southampton, UK.

Received: 7 October 2015 Accepted: 6 December 2015

Published online: 14 December 2015

\section{References}

1. Brandt A, De Broyer C, De Mesel I, Ellingsen KE, Gooday AJ, Hilbig B, et al. The biodiversity of the deep Southern Ocean benthos. Philos Trans R Soc B. 2007;362:39-66.

2. McClain CR, Schlacher TA. On some hypotheses of diversity of animal life at great depths on the sea floor. Mar Ecol. 2015;36:849-872.

3. Hilário A, Metaxas A, Gaudron SM, Howell KL, Mercier A, Mestre NC, et al. Estimating dispersal distance in the deep sea: challenges and applications to marine reserves. Front Mar Sci. 2015;2:1-14.

4. Goffredi SK, Hurtado LA, Hallam S, Vrijenhoek RC. Evolutionary relationships of deep-sea vent and cold seep clams (Mollusca: Vesicomyidae) of the 'pacifica/lepta' species complex. Mar Biol. 2003;142:311-20.

5. Raupach MJ, Malyutina M, Brandt A, Wägele JW. Molecular data reveal a highly diverse species flock within the munnopsoid deep-sea isopod Betamorpha fusiformis (Barnard, 1920) (Crustacea: Isopoda: Asellota) in the Southern Ocean. Deep Sea Res II. 2007;54:1820-30.

6. Brix S, Riehl T, Leese F. First genetic data for species of the genus Haploniscus Richardson, 1908 (Isopoda: Asellota: Haploniscidae) from neighbouring deep-sea basins in the South Atlantic. Zootaxa. 2011;2838:79-84.

7. Zardus JD, Etter RJ, Chase MR, Rex MA, Boyle EE. Bathymetric and geographic population structure in the pan-Atlantic deep-sea bivalve Deminucula atacellana (Schenck, 1939). Mol Ecol. 2006;15:639-51.

8. Havermans C, Sonet G, d'Udekem d'Acoz C, Nagy ZT, Martin P, Brix S, et al. Genetic and morphological divergences in the cosmopolitan deep-sea 
amphipod Eurythenes gryllus reveal a diverse abyss and a bipolar species. PLoS ONE. 2013;8:e74218.

9. Bano N, Ruffin S, Ransom B, Hollibaugh J. Phylogenetic composition of Arctic Ocean Archaeal assemblages and comparison with Antarctic assemblages. Appl Environ Microbiol. 2004;70:781-9.

10. Brinkmeyer R, Knittel K, Jürgens J, Weyland H, Amann R, Helmke E. Diversity and structure of bacterial communities in Arctic versus Antarctic pack ice. Appl Environ Microbiol. 2003;69:6610-9.

11. Pawlowski J, Fahrni J, Lecroq B, Longet D, Cornelius N, Excoffier L, et al. Bipolar gene flow in deep-sea benthic foraminifera. Mol Ecol. 2007;16:4089-96.

12. Herrera S, Shank TM, Sánchez JA. Spatial and temporal patterns of genetic variation in the widespread antitropical deep-sea coral Paragorgia arborea. Mol Ecol. 2012;21:6053-67.

13. Vogler AP, Monaghan MT. Recent advances in DNA taxonomy. J Zool Syst Evol Res. 2007:45:1-10

14. Vrijenhoek RC. Cryptic species, phenotypic plasticity, and complex life histories: Assessing deep-sea faunal diversity with molecular markers. Deep Res II. 2009;56:1713-23.

15. Nygren A. Cryptic polychaete diversity: A review. Zool Scr. 2014;43:172-83.

16. Hilário A, Capa M, Dahlgren TG, Halanych KM, Little CTS, Thornhill DJ, et al. New perspectives on the ecology and evolution of siboglinid tubeworms. PLOS ONE. 2011;6:e16309.

17. Southward E, Schulze A, Gardiner S. Pogonophora (Annelida): form and function. Hydrobiologia. 2005;535:227-51.

18. Dubilier N, Bergin C, Lott C. Symbiotic diversity in marine animals: the art of harnessing chemosynthesis. Nat Rev Microbiol. 2008;6:725-40.

19. Dando PR, Southward AJ, Southward EC, Lamont P, Harvey R. Interactions between sediment chemistry and frenulate pogonophores (Annelida) in the north-east Atlantic. Deep Sea Res I. 2008:55:966-96.

20. Coykendall DK, Johnson SB, Karl SA, Lutz RA, Vrijenhoek RC. Genetic diversity and demographic instability in Riftia pachyptila tubeworms from eastern Pacific hydrothermal vents. BMC Evol Biol. 2011;11:96.

21. Zhang H, Johnson SB, Flores VR, Vrijenhoek RC. Intergradation between discrete lineages of Tevnia jerichonana, a deep-sea hydrothermal vent tubeworm. Deep Sea Res II. 2015;121:53-61.

22. Cowart DA, Huang C, Arnaud-Haond S, Carney SL, Fisher CR, Schaeffer SW. Restriction to large-scale gene flow vs. regional panmixia among cold seep Escarpia spp. (Polychaeta, Siboglinidae). Mol Ecol. 2013;22:4147-62.

23. Li Y, Kocot KM, Schander C, Santos SR, Thornhill DJ, Halanych KM. Mitogenomics reveals phylogeny and repeated motifs in control regions of the deepsea family Siboglinidae (Annelida). Mol Phylogenet Evol. 2015;85:221-9.

24. Webb M. A new bitentaculate pogonophoran from Hardangerfjorden, Norway. Sarsia. 1964;15:49-55.

25. Smirnov RV. Two new species of Pogonophora from the arctic mud volcano off northwestern Norway. Sarsia. 2000;85:141-50.

26. Southward EC. On some Pogonophora from the Carribbean and the Gulf of Mexico. Bull Mar Sci. 1972:22:739-76.

27. Eichinger I, Hourdez S, Bright M. Morphology, microanatomy and sequence data of Sclerolinum contortum (Siboglindae, Annelida) of the Gulf of Mexico. Org Divers Evol. 2013;13:311-29.

28. Southward EC. Pogonophora. In: Weber M, editor. Siboga - Expeditie. Leiden: Brill; 1961. p. 1-22.

29. Ivanov A, Selivanova R. Sclerolinum javanicum sp.n., a new pogonophoran living on rotten wood. A contribution to the classification of Pogonophora. Biol Morya. 1992;1-2:27-33.

30. Sahling H, Wallmann K, Dählmann A, Schmaljohann R, Petersen S. The physicochemical habitat of Sclerolinum sp. at Hook Ridge hydrothermal vent, Bransfield Strait, Antarctica. Limnol Oceanogr. 2005;50:598-606.

31. Sahling H, Galkin S, Salyuk A, Greinert J, Foerstel H, Piepenburg D, et al. Depthrelated structure and ecological significance of cold-seep communities-a case study from the Sea of Okhotsk. Deep Sea Res I. 2003;50:1391-409.

32. Kojima S, Segawa R, Hashimoto J, Ohta S. Molecular phylogeny of vestimentiferans collected around Japan, revealed by the nucleotide sequences of mitochondrial DNA. Mar Biol. 1997;127:507-13.

33. Kojima S, Ohta S, Yamamoto T, Yamaguchi T, Miura T, Fujiwara Y, et al. Hashimoto Molecular taxonomy of vestimentiferans of the western Pacific, and their phylogenetic relationship to species of the eastern Pacific III. Alaysia-like vestimentiferans and relationships among families. Mar Biol. 2003;142:625-35.

34. Aquilina A, Homoky WB, Hawkes JA, Lyons TW, Mills RA. Hydrothermal sediments are a source of water column Fe and Mn in the Bransfield Strait, Antarctica. Geochim Cosmochim Acta. 2014;137:64-80.
35. Vanreusel A, Andersen AC, Boetius A, Connelly D, Cunha MR, Decker C, et al. Biodiversity of cold seep ecosystems along the European margins. Oceanography. 2009;22:118-435.

36. Lazar CS, Dinasquet J, Pignet P, Prieur D, Toffin L. Active archaeal communities at cold seep sediments populated by Siboglinidae tubeworms from the Storegga Slide. Microb Ecol. 2010;60:516-27.

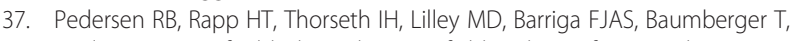
et al. Discovery of a black smoker vent field and vent fauna at the Arctic Mid-Ocean Ridge. Nat Commun. 2010;1:126.

38. Kongsrud JA, Rapp HT. Nicomache (Loxochona) lokii sp. nov. (Annelida: Polychaeta: Maldanidae) from the Loki's Castle vent field: An important structure builder in an Arctic vent system. Polar Biol. 2012;35:161-70.

39. Gaudron SM, Pradillon F, Pailleret M, Duperron S, Le Bris N, Gaill F. Colonization of organic substrates deployed in deep-sea reducing habitats by symbiotic species and associated fauna. Mar Environ Res. 2010;70:1-12.

40. Chown SL, Clarke A, Fraser Cl, Cary SC, Moon KL, McGeoch MA. The changing form of Antarctic biodiversity. Nature. 2015;522:431-8.

41. Klinkhammer GP, Chin CS, Keller RA, Dählmann A, Sahling H, Sarthou G, et al. Discovery of new hydrothermal vent sites in Bransfield Strait, Antarctica. Earth Planet Sci Lett. 2001;193:395-407.

42. Domack $\mathrm{E}$, Ishman $\mathrm{S}$, Leventer A, Sylva S, Willmott V, Huber B. A chemotrophic ecosystem found beneath Antarctic Ice Shelf. EOS Trans Am Geophys Union. 2005;86:269-76.

43. Rogers AD, Tyler PA, Connelly DP, Copley JT, James R, Larter RD, et al. The discovery of new deep-sea hydrothermal vent communities in the Southern ocean and implications for biogeography. PLoS Biol. 2012;10:e1001234.

44. Amon DJ, Glover AG, Wiklund $H$, Marsh L, Linse K, Rogers AD, et al. The discovery of a natural whale fall in the Antarctic deep sea. Deep Sea Res II. 2013;92:87-96.

45. Aquilina A, Connelly DP, Copley JT, Green DRH, Hawkes JA, Hepburn LE, et al. Geochemical and visual indicators of hydrothermal fluid flow through a sediment-hosted volcanic ridge in the central Bransfield basin (Antarctica). PLoS ONE. 2013;8:e54686

46. German CR, Livermore RA, Baker ET, Bruguier NI, Connelly DP, Cunningham AP, et al. Hydrothermal plumes above the East Scotia Ridge: an isolated high-latitude back-arc spreading centre. Earth Planet Sci Lett. 2000;184:241-50.

47. Winkler G, Newton $\mathrm{R}$, Schlosser $\mathrm{P}$, Crone T. Mantle helium reveals Southern Ocean hydrothermal venting. Geophys Res Lett. 2010;37:L05601.

48. Hahm D, Baker ET, Rhee TS, Won Y-J, Resing JA, Lupton JE, et al. First hydrothermal discoveries on the Australian-Antarctic Ridge: Discharge sites, plume chemistry, and vent organisms. Geochem Geophys Geosyst. 2015;16.

49. Tyler PA. Cruise Report No. 05 RRS James Cook Cruise JC55 13 JAN-22 FEB 2011 Bransfield Strait, the East Scotia Ridge and the Kemp Seamount Calderas Cruise 3 of the NERC Consortium Grant 'Chemosynthetically-Driven Ecosystems in the Southern Ocean'. 2011. p. 1-85.

50. Webb M. Tube abnormality in Siboglinum ekmani, S. fiordicum and Sclerolinum brattstromi (Pogonophora). Sarsia. 1964;15:69-70.

51. Bell JB, Woulds C, Brown LE, Little CTS, Sweeting CJ, Reid WD , Glover, AG. Macrofaunal ecology of sedimented hydrothermal vents in the Bransfield Strait, Antarctica. Front Mar Sci. 2015 (accepted).

52. Dählmann A, Wallmann K, Sahling H, Sarthou G, Bohrmann G, Petersen S, et al. Hot vents in an ice-cold ocean: Indications for phase separation at the southernmost area of hydrothermal activity, Bransfield Strait, Antarctica. Earth Planet Sci Lett. 2001;193:381-94.

53. Hebert $P$, Ratnasingham S, DeWaard J. Barcoding animal life: cytochrome C oxidase subunit 1 divergences among closely related species. Proc R Soc B. 2003:270:596-9.

54. Carr C, Hardy S, Brown T. A tri-oceanic perspective: DNA barcoding reveals geographic structure and cryptic diversity in Canadian polychaetes. PLoS ONE. 2011;6:e22232.

55. Longmore C, Trueman CN, Neat F, Jorde PE, Knutsen H, Stefanni S, et al. Ocean-scale connectivity and life cycle reconstruction in a deep-sea fish. Can J Fish Aquat Sci. 2014;71:1312-23.

56. O'Hara TD, England PR, Gunasekera RM, Naughton KM. Limited phylogeographic structure for five bathyal ophiuroids at continental scales. Deep Sea Res I. 2014;84:18-28.

57. Walz KR, Clague DA, Barry JP, Vrijenhoek RC. First records and range extensions for two Acesta clam species (Bivalvia: Limidae) in the Gulf of California, Mexico. Mar Biodivers Rec. 2014;7:e60. 
58. Breusing C, Johnson SB, Tunnicliffe V, Vrijenhoek RC. Population structure and connectivity in Indo-Pacific deep-sea mussels of the Bathymodiolus septemdierum complex. Conserv Genet. 2015;16:1-16.

59. Audzijonyte A, Vrijenhoek RC. When gaps really are gaps: Statistical phylogeography of hydrothermal vent invertebrates. Evolution. 2010;64:2369-84.

60. Marsh AG, Mullineaux LS, Young CM, Manahan DT. Larval dispersal potential of the tubeworm Riftia pachyptila at deep-sea hydrothermal vents. Nature. 2001:411:77-80

61. Feldman R, Shank T, Black M, Baco A, Smith C, Vrijenhoek R. Vestimentiferan on a whale fall. Biol Bull. 1998;194:116-9.

62. Glover AG, Källström B, Smith CR, Dahlgren TG. World-wide whale worms? A new species of Osedax from the shallow north Atlantic. Proc R Soc B. 2005;272:2587-92.

63. Fuerst PA, Maruyama T. Considerations on the conservation of alleles and of genic heterozygosity in small managed populations. Zoo Biol. 1986;5:171-9.

64. Riesgo A, Taboada S, Avila C. Evolutionary patterns in Antarctic marine invertebrates: An update on molecular studies. Mar Genomics. 2015;23:1-13.

65. Allcock AL, Strugnell JM. Southern Ocean diversity: New paradigms from molecular ecology. Trends Ecol Evol. 2012;27:520-8.

66. Webb M. Additional notes on Sclerolinum brattstromi (Pogonophora) and the establishment of a new family, Sclerolinidae. Sarsia. 1964;16:47-58.

67. Southward EC. Development of Perviata and Vestimentifera (Pogonophora). In: Reproductive Strategies and Developmental Patterns in Annelids. Netherlands: Springer; 1999. p. 185-202.

68. Danise S, Higgs ND. Bone-eating Osedax worms lived on Mesozoic marine reptile deadfalls. Biol Lett. 2015;11:20150072.

69. Halanych K, Lutz R, Vrijenhoek R. Evolutionary origins and age of vestimentiferan tube-worms. Cah Biol. 1998;39:355-8.

70. Chevaldonné $P$, Jollivet $D$, Desbruyeres $D$, Lutz R, Vrijenhoek RC. Sisterspecies of eastern Pacific hydrothermal vent worms (Ampharetidae, Alvinellidae, Vestimentifera) provide new mitochondrial COl clock calibration. Cah Biol. 2002;43:367-70.

71. Hurtado LA. Evolution and biogeography of hydrothermal vent organisms in the Eastern Pacific Ocean. Ph.D. thesis. Rutgers University, New Brunswick, N.J.; 2002

72. Jablonski D. Extinctions: a paleontological perspective. Science. 1991;253:754-7.

73. Southward EC, Tunnicliffe V, Black M. Revision of the species of Ridgeia from northeast Pacific hydrothermal vents, with a redescription of Ridgeia piscesae Jones (Pogonophora: Obturata = Vestimentifera). Can J Zool. 1995;73:282-95.

74. Tunnicliffe V, St. Germain C, Hilário A. Phenotypic variation and fitness in a metapopulation of tubeworms (Ridgeia piscesae Jones) at hydrothermal vents. PLOS ONE. 2014;9:e110578.

75. Baker HG. The evolution of weeds. Annu Rev Ecol Syst. 1974;5:1-24

76. Van Dover CLL, German CRR, Speer KGG, Parson LMM, Vrijenhoek RCC. Evolution and biogeography of deep-sea vent and seep invertebrates. Science. 2002;295:1253-7.

77. Vrijenhoek RC. Genetic diversity and connectivity of deep-sea hydrothermal vent metapopulations. Mol Ecol. 2010;19:4391-411.

78. Macdonald I, Loope L, Usher M, Hamann O. Wildlife conservation and the invasion of nature reserves by introduced species: a global perspective. In: Biological invasions: a global perspective. New York: Wiley; 1989. p. 215-55.

79. Gordon DR. Effects of invasive, non-indigenous plant species on ecosystem processes: lessons from Florida. Ecol Appl. 1998;8:975-89.

80. Cole CS, James RH, Connelly DP, Hathorne EC. Rare earth elements as indicators of hydrothermal processes within the East Scotia subduction zone system. Geochim Cosmochim Acta. 2014;140:20-38.

81. Rousset V, Rouse GW, Siddall ME, Tillier A, Pleijel F. The phylogenetic position of Siboglinidae (Annelida) inferred from 185 rRNA, 28S rRNA and morphological data. Cladistics. 2004;20:518-33.

82. Weigert A, Helm C, Meyer M, Nickel B, Arendt D, Hausdorf B, et al. Illuminating the base of the Annelid tree using transcriptomics. Mol Biol Evol. 2014:31:1391-401

83. Kearse M, Moir R, Wilson A, Stones-Havas S, Cheung M, Sturrock S, et al. Geneious Basic: An integrated and extendable desktop software platform for the organization and analysis of sequence data. Bioinformatics. 2012;28:1647-9.

84. Edgar RC. MUSCLE: multiple sequence alignment with high accuracy and high throughput. Nucleic Acids Res. 2004;32:1792-7.
85. Katoh K, Misawa K, Kuma K, Miyata T. MAFFT: a novel method for rapid multiple sequence alignment based on fast Fourier transform. Nucleic Acids Res. 2002;30:3059-66.

86. Posada D. jModelTest: Phylogenetic Model Averaging. Mol Biol Evol. 2008:25:1253-6

87. Ronquist F, Huelsenbeck JP. MRBAYES 3: Bayesian phylogenetic inference under mixed models. Bioinformatics. 2003;19:1572-4.

88. Tamura K, Peterson D, Peterson N, Stecher G, Nei M, Kumar S. MEGA5: molecular evolutionary genetics analysis using maximum likelihood, evolutionary distance, and maximum parsimony methods. Mol Biol Evol. 2011;28:2731-9.

89. Clement M, Posada D, Crandall K. TCs: a computer program to estimate gene genealogies. Mol Ecol. 2000;9:1657-60.

90. Librado P, Rozas J. DnaSP v5: A software for comprehensive analysis of DNA polymorphism data. Bioinformatics. 2009:25:1451-2.

91. Excoffier $L$, Lischer $H$. Arlequin suite ver 3.5: a new series of programs to perform population genetics analyses under Linux and Windows. Mol Ecol Resour. 2010;10:564-7.

92. Ryan WBF, Carbotte SM, Coplan JO, O'Hara S, Melkonian A, Arko R, et al. Global multi-resolution topography synthesis. Geochem Geophys Geosyst. 2009;10:Q03014

\section{Submit your next manuscript to BioMed Central and we will help you at every step:}

- We accept pre-submission inquiries

- Our selector tool helps you to find the most relevant journal

- We provide round the clock customer support

- Convenient online submission

- Thorough peer review

- Inclusion in PubMed and all major indexing services

- Maximum visibility for your research

Submit your manuscript at www.biomedcentral.com/submit
) Biomed Central 